\title{
THE WRITTEN ASPECT OF INDORSEMENT
}

\author{
Herschel W. Arant
}

Several years ago, Professor Ames complained" that an "excellent opportunity to unify the law was neglected" as a result of the failure, in the Negotiable Instruments Law, to formulate a definition of indorsement which would remove the conflict of decision in cases where the payee writes: "I assign this note to B" or "I guarantee the payment of this note to B."2 In each of these situations, there was con'flict as to whether the maker's defenses were cut off and as to whether the writer had undertaken as indorser. The persistent conflict of opinion upon these very practical questions indicates that unification or clarification would have been desirable. Save in the Illinois act, however, nothing was done and the confusion persists. ${ }^{3}$ The writer proposes, for this reason, to discuss the cases in which typical groups of words, claimed to be indorsements, have been passed upon by the

${ }^{2}$ The Negotiable Instrumerts Lare (Igoo) I4 HARv. L. REv. 24I, 443.

'In the Negotiable Instruments Law, negotiation is defined as follows:

"An instrument is negotiated when it is transferred from one person to another in such manner as to constitute the transferee the holder thereof. If payable to bearer it is negotiated by delivery; if payable to order it is negotiated by the indorsement of the holder completed by delivery." N. I. L., sec. 3 I.

Indorsement is defined as follows:

"The indorsement must be written on the instrument itself or upon a paper attached thereto. The signature of the indorser, without additional words, is a sufficient indorsement." N. I. L., sec. 3I.

"To section 3I the Illinois act adds "and the addition of words of assignment or guaranty shall not negative the additional effect of the signature as an indorsement, unless otherwise expressly stated." Hurd's I11. Rev. Sts. I9I9, ch. 98, sec. 49. This addition was doubtless intended to meet the need referred to by Professor Ames but, if words of assignment are used, it is not clear that it is adequate where the question is whether the maker's defenses are cut off, though it leaves no doubt that the indorser's undertaking exists.

In Dunham v. Peterson ( 1896 ) 5 N. D. 4I4, 67 N. W. 293, where the maker was sued by a transferee of a payee, who had written "For value received, I hereby guaranty the within note, waiving notice of protest and demand," the court held that the maker's defenses were cut off and it was said that the matter was set at rest in that state by a statute which provided that "One who writes his name on a negotiable instrument, otherwise than as maker or acceptor, and delivers it with his name thereon to another person, is called an indorser, and his act is called indorsement." N. D. Rev. Code, I899, ch. 88, sec. 4868 . This provision is practically the same as N. I. L., sec. 63, which provides that "A person placing his signature upon an instrument otherwise than as maker, drawer or acceptor, is deemed to be an indorser, unless he clearly indicates by appropriate words, his intention to be bound in some other capacity." Very.few instances have been noted, however, where this section has been relied upon in the solution of the problems presented by the cases here discussed. Mangoldt \& Glandt Bank v. Utterback (1916) 54 Okla. 655, I60 Pac. 713; Farnsworth v. Burdick (I915) 94 Kan. 749, I47 Pac. 863. 
courts and suggest what seem to be proper conclusions. ${ }^{4}$ These alleged indorsements, as to their form, are roughly divisible into assignments and guaranties. For convenience, they will be discussed separately.

\section{ASSIGNMENTS}

Suits Against the Maker. Where the maker is sued, "I assign the within note" is held to be sufficient indorsement to cut off the maker's defenses." Where such words are followed by "without recourse" most courts would now probably hold the same view. ${ }^{8}$ Where the "right," "title," "interest," "right and title" or "right, title and interest" in the note is assigned or transferred, even when "without recourse" is added, the more general view is that the maker's defenses are destroyed. ${ }^{7}$ Hatch v. Barrett ${ }^{8}$ and Gale v. Mayhew ${ }^{9}$ are the only two strong assignment cases in which a contrary result was reached. The reasoning in these cases is interesting and worth examination.

In Hatch $v$. Barrett, the maker sought the cancellation of a note and mortgage on the ground of duress. The payee had written on the back of the note: "I, J. C. Rogers, do hereby assign the within note to Charles B. Hatch, of Osage County, Kansas. Said assignment is made without recourse on me either in law or equity." The defendant claimed to be a holder in due course. The court held that the writing was not an indorsement and decreed cancellation.

Horton, C. J., said :10

"The question is whether this writing can be considered in a commercial sense an indorsement. If the note was not 'indorsed' to Hatch, it was not taken by him in the usual course of business by the mode of transfer in which negotiable paper is usually transferred. A negotiable promissory note, if payable to order, can be assigned free from all equities only by endorsement, for there is no statute in this state that authorizes a negotiable promissory note, payable to order, to be trans-

\footnotetext{
"Cases involving simple "protest waived" and "without recourse" indorsements, both of which are well understood, are not discussed here; nor the cases involving questions as to delivery, value or bona fides. The discussion here assumes the existence of these latter elements and is confined to those cases that have raised problems as to whether certain written groups of words, not so clear in their import as "without recourse" or "protest waived," constitute the indorsement that is conceded to be essential to the negotiation of an "order" instrument.

${ }^{5}$ Farnsworth v. Burdick, supra note 3.

${ }^{\circ}$ Lealiy v. Haworth (1905, C. C. A. 8th) I4I Fed. 850, 73 C. C. A. 84. See Brotherton v. Street (I890) I24 Ind. 599, 24 N. E. I068; contra: Hatch v. Barrett (1885) 34 Kan. 223, 8 Pàc. I29. See De Hass v. Roberts (1894, C. C. W. D. Pa.) 59 Fed. 853 .

${ }^{7}$ Bisbing v. Grahan. (1849) I4 Pa. I4; Merrill v. Hurley (1895) 6 S. D. 592, 62 N. W. 958 ; Evans v. Freeman (1906) I42 N. C. 6r, 54 S. E. 847 ; contra: Gale v. Mayhew (1910) I6r Mich. 96, I25 N. W. 78ז. See Aniba v. Yeomans (IS78) 39 Mich. I7I.

${ }^{8}$ Supra note 6.

'Supra note 7.

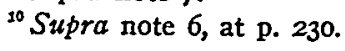


ferred free from all or any equitable defenses or claims except by indorsement. Comp. Laws of 1879 , ch. I4, sec. I; McCrum v. Corby, II Kan. 464.

"The alleged indorsement is clearly not in the usual or common form but is substantially different therefrom. The words of the indorsement, taken together, must be treated only as an assignment of the note. An assignee stands in the place of the assignor, and takes simply an assignor's rights; but the assignment of a note will not cut off the defenses of the maker .......

"Of course, we understand that an indorsement qualified by the words 'without recourse' is not out of the course of trade, and does not throw any suspicion upon the character of the paper. A note continues negotiable, notwithstanding the words without recourse; but in this case, the indorsement goes further than mere words 'without recourse,' and therefore as before stated, we cannot consider the writing by which the note zeas transferred as an indorsement in a commercial sense. If parties accept paper with the indorsement 'without recourse,' with the expectation that the paper is negotiable, the indorsement ought to be made in strict compliance with the technical rules of commercial law, in this way: 'Without recourse. John Doe' or 'Pay to Richard Roe, or order, without recourse. John Doe.' or in some other like form." (Italics are the present writer's.)

It will be observed that the learned court suggests that only those words that are usually and commonly used upon the transfer of negotiable paper comply sufficiently strictly with the requirements of the technical rules of commercial law to be indorsements. If, however, a payee should write out in full the implications of the ordinary blank indorsement, as, for example, "I hereby assign this note to $X$, order the maker to pay him, and agree to pay said note if the maker does not pay it.upon presentment at maturity and I am given the customary notice of dishonor," there can be little doubt that the courts would hold such a writing to be an indorsement, though "it is clearly not in the usual or common form." No authority was cited and none has been found that suppoirts the suggestion that particular legal consequences may be produced only by limited aggregates of words. On the other hand, other courts have said that the form of words used is unimportant.11 It is well settled that usual and common forms of words are not necessary to the existence of a negotiable promissory note or bill of exchange; very unusual and informal instruments have been held to be such. The sole requirement has always been that the writing, within its four corners, show an intent to make a promise or an order

\footnotetext{
${ }^{11}$ For example, in Patillo v. Alexander (1895) 96 Ga. 60, 66, 22 S. E. 646, 648, Atkinson, J., said: "The form of words used in making this contract is not specially important, except in so far as it serves to throw light upon the nature of the undertaking upon the part of the payee who signed it. It is the purpose designed to be accomplished and which is legally accomplished by the fact of indorsement, which must at last determine the nature and character of the contract." In Merrill v. Hurley, supra note 7, at p. 602, the court said: "Any form which manifests an intention to transfer a negotiable promissory note is sufficient to constitute an indorsement."
} 
of the sort that will be a satisfactory substitute for money in commercial transactions. If no particular forms of words are essential to the validity of a bill or a note that will circulate in commercial channels it is, to say the least, unreasonably arbitrary to hold that a transfer in a commercial transaction of such an instrument, either with or without the indorser's promise, is to be given the effect required by the needs of business only when "the usual and common form is used."12

"Indorse," "assign" and "transfer," with reference to negotiable paper, are sometimes used interchangeably. The learned court, for example, in a single sentence quoted above, speaks' of instruments being both "assigned" and "transferred" free from defenses, evidently meaning by each expression the same thing, and says neither can be done except by an indorsement. They are frequently used merely to denote the physical acts of the transferror and at other times they are said to connote the legal consequences of what a transferror has done. The word "indorsement" is used to designate any written words on an instrument that show a transferror's intent merely to terminate his ownership and this is so whether such words are written upon the instrument before or after maturity. But it denctes also the mere signature of the transferror, as well as the various groups of words which he may add to show his intention to accompany the transfer with his conditional promise to pay the instrument. When so many different groups of words may be used to produce the conveyance consequence of indorsement, either alone or accompanied by the indorser's undertaking, and when it is clear that a given group of words may be entirely adequate for the former purpose and inadequate for the latter, and when any one of them is properly called an indorsement, it is obvious that no premise may be constructed, containing the word indorse or indorsement, from which it is safe to reason when the problem is whether a particular group of words shall have particular consequence. As will be noted, however, the learned court so used such a premise in Hatch v. Barrett.

\footnotetext{
${ }^{12}$ The conditional promise of the indorser is not essential to such a negotiation as will destroy the maker's defenses but courts have sometimes reasoned as if it were an indispensable part of the indorsement that is essential to such a negotiation. In Sears $v$. Lantz and Bates (1878) 47 Iowa, 658 , the suit was against a payee-indorser, who had written: "I hereby assign all my" right and title to Louis Meckley." The court gave-judgment for the plaintiff, saying at p. 659: "It must be regarded as settled in this State that the assignment of a promissory note by the payee thereof, in writing on the note, vests the legal title therein in the assignee so as to enable him to bring an action in his own name against the maker. Such being true an assignment amounts to an indorsement, and makes the assignor liable as indorser." The assumption of the learned court that a transferror who indorses paper necessarily undertakes as indorser is obviously unfounded. A better reason for the decision would have been that the transferror had not shown clearly enough his intent not to undertake as indorser to enable the court to excuse him without impeding the circulation of commercial paper as a substitute for money.
} 
In the first paragraph quoted above, the learned court began its syllogism with the major premise that "a negotiable promissory note can be assigned free from all equities only by an indorsement." "This note was not assigned by an indorsement" or "this note was assigned by an assignment" was the minor premise and the conclusion followed that the instrument was not "assigned" free from equities. It was assumed that indorsement and assignment were separate and distinct factual operations and the court's logic assumed that the transferror had performed the latter operation in the case in question. Yet, according to the court, all indorsements of negotiable paper include or are assignments as well. But it is suggested that assignments do not always include or are not always indorsements. ${ }^{13}$ Whether this is true or not depends upon whether "indorse" denotes the transferror's acts or their legal consequences. As a mere assertion by the transfer or of what he does, any one of the groups of words herein referred to may properly be called either an indorsement or an assignment and it seems clear that it is the appearance of such words on the back of a negotiable instrument with their clear manifestation of the transferror's intention to order payment to another that makes them have the legal consequence of destroying the maker's defenses. ${ }^{14}$

In Hatch v. Barrett, if "indorse" had been used instead of "assign,"

${ }^{13}$ In Lyons v. Develbis ( 1853 ) $22 \mathrm{~Pa}$. 185, the defendant was sued as indorser of a note on which he had written, "I assign the above note to J. D." Because the plaintiff had violated the agreement under which he had received the note, he was denied a recovery. But Lewis, J., at p. 189 , said:

"Every indorsement of a promissory note includes in it an assignment, but an assignment is not necessarily an indorsement. The statute of 3 and 4 Anne, Chapter IX, distinguishes between the two methods of transfer, when it authorizes the holder, whether by endorsenent or assignment, to bring an action in his own name against the maker, and endorser. No action is given by the statute against the assignor."

${ }^{14}$ In Kilpatrick v. Heaton (I8I2 S. C.) 3 Brev. 92, the defendant had written: "I assign the within note to Jas. Kilpatrick." No notice of dishonor having been given, the plaintiff was denied a recovery and the court doubted whether he could have recovered under any circumstances. Brevard, $J$., at p. 93, said:

"Yet, if a negotiable note be assigned, it rather seems to me that the assignee must take it as assignee, and cannot take it as indorsee. This may seem to be a distinction merely nominal. . . . .

"This statute ( 3 and 4 Anne) makes them (promissory notes) assignable and indorsable over, in the same manner as inland bills of exchange; and declares that the indorsee may maintain an action thereon, as on a bill of exchange. I know not if this statute meant to make any difference between the assignment and indorsement of a note.

"Indorsements are either full, or in blank. A full indorsement is that by which the indorser orders the money to be paid to some particular person by name. Kyd on Bills and Notes 59. This was not a blank indorsement. It was not an indorsement to pay the money to any particular person. It may, however, be said, that indorsement and assignment, in relation to negotiable instruments are convertible terms, and that the assignment in question imports an order to pay - the money to the assignee, as indorsee.

"I am not clear that this position is not sound: yet, I rather incline to think it is fair to conclude, from the terms of the assignment, that the assignor did not intend to make himself liable as indorser."

See Comments (igig) 29 Yale LaW Journal, 102. 
the decision would probably have been the opposite because the court would have considered the "indorsement" stamp to have been placed upon the operation. But if the note had been non-negotiable, it would have made no difference that it was indorsed in the most "usual and common form." The maker's defenses would be good. Whether the instrument be negotiable or not, however, the intention of the transferror to vest ownership in another is equally apparent, when he parts with the instrument, whether he says he "assigns," "transfers" or "indorses" the note or his "right," "title" or "interest" in the note and the irresistible inference from such language is an order to the maker to pay the transferee. This inference is recognized in the rule that, where a non-negotiable promise to pay money is assigned, the obligor, with notice of the assignment and without a defense, has no power to extinguish his duty except by payment to the assignee. But the obligee in an ordinary chose in action at common law was without power to assign, transfer or indorse so that the assignee, transferee or indorsee would take free from equities. Nor could the transferee of such a chose in action have recourse for payment to the transferror in case the obligor did not perform, unless there was some special agreement. The "assignment," "transfer" or "indorsement" of only those choses in action that were suitable as a substitute for money and customarily so used by the merchants had as a legal consequence the destruction of the obligor's defenses. That the transfer of even these choses in action was followed by this consequence was not in deference to the intent or desire of the promisee but because it was desirable that the necessity of using money in every business transaction be avoided. The exigencies of business required the existence of rules that would tempt persons to whom money needed to be paid to accept instead a chose in action to the end that the transportation of money with its expense and risk of loss might be avoided. The intent of the transferror as to the transferee's rights against the obligor, if he had any other than that they should be similar to what he himself had had was never expressed and, if expressed, would probably be of no effect unless its expression prevented the taking of the instrument in good faith. ${ }^{15}$

\footnotetext{
${ }^{25}$ But see Hailey $v$. Falconer (1858) 32 Ala. 536, where the defendant had written: "I transfer unto- all my right and title in the within note, to be enjoyed in the same manner as may have been by me." Because the defendant had clearly shown an intent not to undertake as indorser, he was held not liable. But Rice, C. J., at p. 540, added:

"The words of indorsement, taken together, and so reconciled as to allow some meaning and effect to each word in it, naturally import no more than mere substitution and subrogation-the substitution of the endorseo for the endorser, and the subrogation of the former to all the right and title of the latter in the note,

In the cases now under discussion, the payee never had a right that the maker pay according to the tenor of his promise but he has a power to create such a right by indorsing the paper to a good faith taker for value. Society, in such a case, decrees the destruction of the promisor's defenses because the needs of business require it.
} 
The conclusion, therefore, seems clear that any language, written upon or attached to the instrument, that is reasonably indicative of an intent to transfer is all the indorsement that is essential to such a negotiation as will cut off the maker's defenses. The learned court, in Hatch v. Barrett, erred in assuming that there was a difference between an assignment written upon a negotiable instrument and an indorsement, that the former must be followed by the same legal consequences that followed a written assignment of an ordinary chose in action at common law and that indorsement can be accomplished only by those forms of words that are usually and commonly used when negotiable paper is transferred.

In Gale v. Mayhew, the payee wrote on the back of the note "I hereby assign my interest in this note to Wm. H. Gale," and delivered it to Gale, who sued the maker in his own name. A statute provided that an assignee of a chose in action "not negotiable under existing laws" could sue and recover in his own name.17 The learned court, distinguishing the case from Markey $v$. Corey ${ }^{18}$ where the transferror had written "I hereby assign the within note to ....", held that there could be no recovery.

Whether the legislature intended such a result as the court reached may well be doubted. A request for the enactment of a provision that a writing on the back of a non-negotiable instrument, such as appeared in Gale v. Mayhew, should enable the assignee to sue in his own name but the same writing on the back of a negotiable note should confer no such power would doubtless have been refused because of the utter lack of reason for producing such a distinction. The power conferred by the act referred to was probably limited to assignees of choses in action not negotiable under existing laws because of the impression that an assignee of a chose in action negotiable under existing laws was already able to sue in his own name.

Here, as in Hatch $v$. Barrett, the court proceeds on the assumption that there are definite and distinct factual operations that the words "assignment" and "indorsement" designate and that, irrespective of what kind of a chose in action it is that is being transferred, when "assign" is used, the former operation takes place and all the legal consequences of the assignment of an ordinary chose in action at common law must follow. It was not perceived how words of assignment could make the transferror anything other than an assignor or the transferee anything other than an assignee ${ }^{19}$ notwithstanding the fact that Michigan had already adopted the Negotiable Instruments Law which provided that "A qualified indorsement constitutes the indorser a mere assignor of the title to the instrument." ${ }^{\text {"20 }}$ The outstanding

\footnotetext{
${ }^{26}$ Supra note 7.

${ }^{17} 3$ Mich. Comp. Laws, 19r5, sec. 12468 (7).

as (I895) I08 Mich. 184, 66 N. W. 493.

${ }^{10}$ Compare the first paragraph quoted from Brevard, J., supra note I4.

${ }^{50} 2$ Mich. Comp. Laws, rgr5, ch. IIg, sec. 6079.
} 
characteristic of a qualified indorsement is that it negatives the intention to undertake as indorser, but the taker of an instrument so indorsed can not only sue in his own name but it is well settled that he can recover in spite of the maker's defenses. It was the opinion of the learned court that "I assign my interest in this note" negatived the intention to undertake as indorser and that since the transferror was not an indorser, the paper was not indorsed, notwithstanding the fact the writing thereon clearly indicated the intent of the transferror to order the maker to pay the transferee. This reasoning attributes to "assign" an arbitrary significance that is at variance with usage and entirely disregards the necessity of so resolving all doubts as to the meaning of words that the circulation of commercial paper as a substitute for money will be encouraged.

Suits Against the Indorser. Where an alleged indorser is sued, he is generally held liable where his signature is preceded by a statement that he "assigns" or "transfers" or "transfers and assigns" or "sells and delivers" or "transfers, assigns and indorses" the note ${ }^{21}$ or his "interest" or his "right, title and interest" in the note. ${ }^{22}$ The question is usually

${ }^{21}$ Sands v. Wood (1855, Iowa) I Clark 263; Henderson v. Ackelmire (I877) 59 Ind. 540; Davidson v. Powell (1894) II4 N. C. 575, 19 S. E. 60I; Markey v. Corey, supra note I8; Maine Trust \& Banking Co.v. Butler (189I) 45 Minn. 506, 48 N. W. 333 ; Smith v. Brooks (I880) 65 Ga. 356; Adams v. Blethen (I8;6) 66 Me. I9. See Dixon v. Clayville (1876) $44 \mathrm{Md}$. 573; Marks \& Co. v. Herman (1872) 24 La. Ann. 335 ; contra: see Kilpatrick v. Heaton, supra note $1_{4}$; Lyons v. Develbis, supra note I3.

In McLaughlin v. Duffield ( 1848 , Va.) 5 Gratt. I33: "I assign the within bond (a promissory note) to $M$ and agree not to take any legal advantage of said $M$ in the indulgence he may give" was held to have the effect of waiving presentment of notice and dishonor.

In Duffy's Admr. v. O'Conner (1874) 66 Tenn. 498, "For value received, I assign the within note to - , on condition that the property of the maker's and indorser's be exhausted before recourse on me" was held to have the effect of simply adding one condition to the ordinary indorser's undertaking.

${ }^{2}$ Sears v. Lantz \& Bates, supra note 12 ; Citizen's Nat. Bank v. Walton (I898) 96 Va. 435, 3I S. E. 890; Hurt v. Wiley (rgr6) r8 Ga. App. 420, 89 S. E. 494; Copeland v. Butke (1916) 59 Okla. 219, I58 Pac. II62. See Shelby v. Judd (I880) 24 Kan. I6I; contra: Hailey v. Falconer, supra note I5; Aniba v. Yeomans, supra note 7; Spencer v. Halpern (I896) 62 Ark. 595, 37 S. W. 7II; Ellsworth v. Varney (1898) 83 IIl. App. 94; Hammond Lumber Co. v. Kearsley (I918) 36 Calif. App. 43I, I72 Pac. 404.

In Evans v. Frecman, supra note 7, which arose under the N. I. L., "I hereby assign all my right, title and interest in the within note" was said to be similar in import to "without recourse."

In De Hass $v$. Roberts, supra note 6, the payee of a promissory note, upon transfer, wrote: "For value received, we hereby assign and transfer the within bond, together with all our interest in and rights under the same, without recourse, to John Dibert \& Co." They in turn indorsed, "Pay to the order of F. S. De Hass." The suit was by the executor of De Hass against the surviving partner of Dibert \& Co., as indorser. The court, citing Hatch v. Barrett, supra note 6 , denied a recovery and said that, since the note had not been indorsed by the payees, the legal title to it remained in them. The payee's writing was 
said to be whether his words indicate an intention to undertake as indorser. Some courts have said that the maxim "Expressio qui tacite insunt nihil operatur" is applicable and have held the defendant liable. Other courts, however, have said that such words indicate merely an intent to transfer and, applying the maxim "Expressio unius est exclusio alterius," have held the defendant not liable. In a few cases, without reference to these maxims, it has been held that the making of a simple assignment shows that the transferror did not intend to undertake as indorser. In one case, it was said that the transferror's statement that he "transfers" or "assigns" his interest in the instrument operates only as conveyance and that to give it the legal effect of making him liable as indorser would do violence to the plain meaning of his words, since the interest which he says he transfers includes no such undertaking. ${ }^{23}$

In Lyons v. Develbis, where an "assignor" was held not" liable as indorser, the Court said :24

"An endorsement is an authority to the holder to write over the signature an order upon the maker, in the nature of a bill of exchange. It is a commercial transaction, and the law merchant fixes the measure of liability, as in bills of exchange. An assignment of a chose in action is in strictness unknown to the common law. It is, however, recognised in equity, and transfers to the holder the rights of the assignor, at a price presumed to be no more than equal to the value of the claim against the maker, taking into consideration his çharacter for punctuality, and his ability to pay. On such a transfer the assignor is responsible for nothing but the genuineness of the claim. The instrument on which this action was brought, is a transfer of the description last mentioned, written upon a note overdue at the time. On this there is no resort for indemnity against the insolvency of the maker."

None of such reasoning is entirely satisfactory. It proceeds on the - assumption, already referred to, that a transferror who uses the word "assign," intends to specify as the legal result of his act or that there is some reason why the courts must make such the legal result of his act that familiar group of legal consequences that resulted from the assignment at common law of an ordinary chose in action. None of

said to make the instrument non-negotiable and persons indorsing thereafter were said merely to guarantee the instrument to be genuine and what it purports to be. But, irrespective of whether the instrument is payable to order or not, the payee's writing in De Hass $v$. Roberts was clearly an unconditional order upon the maker to pay the transferee a sum certain in money at a fixed or determinable future time. This constitutes the person so indorsing the drawer of a bill of exchange. The Circuit Court of Appeals, reversing the decision of the Circuit Court, expressed this view. De Hass v. Roberts, supra note 6; Smith v. Brooks, supra note 2I. But the authorities are divided. See Patee Plow Co. $v$. Beard (I910) 27 Okla. 239, I10 Pac. 752, and note in Ann. Cas. I9I2 B, 704 collecting the cases. Whether the maker's defenses can be asserted against a transferee in such a case is, of course, an entirely different question.

${ }^{23}$ Hanmond Lumber Co. v. Kearsley, supra note 22 .

"Supra note 13, at p. 189. 
the words used in the cases referred to were necessary to effect the obviously intended transfer of the title to the instrument, as the signature alone would have accomplished that, but they do appropriately express the transfer implication of a blank indorsement, and the question is whether the expression of this implication leaves the same basis to imply the indorser's undertaking that exists when the transferror's signature alone appears. Whether the transferror is held as indorser should depend, even if the most favorable attitude toward him is taken, not on what he actually intended but on what an ordinary prudent man would believe that he intended; and, in the interpretation of his words, it must be borne in mind that they appear on a negotiable instrument. If they are of doubtful import, it is clear that the adoption of the view that he is an indorser will have the desirable effect of producing a greater circulation of paper as a substitute for money. So long as this is considered desirable, it is not enough to hold a transferror as indorser only when he shows clearly that he intends to be so bound, but it is necessary and, because transferrors do so generally undertake as indorsers, it is also reasonable and fair to hold as an indorser any transferror who does not clearly negative the intention to be so bound. Mere words of assignment or transfer do not show the clear negative required. ${ }^{25}$

${ }^{25}$ The real justification for holding "assignors" as indorsers appears to be its tendency to increase the circulation of commercial paper as a substitute for money.

In Citizens National Bank v. Walton, supra note $2 \mathrm{r}$, in which an "assignor" was sued as indorser, the court, noting that the authorities were in conflict, held that the defendant was liable, saying: "This view seems not only consonant to reason, but is essential to the credit of negotiable paper and to the convenience of commercial transactions."

In a similar case, Copeland v. Burke, supra note 22 at $\mathrm{p} .22 \mathrm{I}$, the Supreme Court of Oklahoma said:

"This question not having heretofore been presented to this court, we feel constrained to adopt the construction placed upon the indorsements of this character by the last-cited line of authorities, as supported by the better reasoning and more in consonance with the commercial needs of the day. In these modern times commercial paper has come to play a very large part in the business life of the country. Commerce is carried on by means of business credit. Commercial paper in great volume continuously passes current by indorsement. The effect of and the liability incurred by an indorsement is a matter of common knowledge. The phrase, 'without recourse,' as employed in such business transactions, is on everyday use, and we can hardly conceive of a person engaged in business affairs of importance, as was the defendant in this case, who is not familiar with its use and meaning. If the defendant did not intend to be bound by his indorsement on the note in-question, he should have used some words which would clearly indicate that he was not an ordinary indorser."

More often, however, the courts are satisfied to sustain this conclusion with a mere statement of some rule of interpretation, similar to that which appears in the conclusion of the preceding quotation, without giving any reason which requires the existence of the rule stated.

The following are typical:

"The effect of the assignment in Sands $v$. Wood was to assign and transfer whatever title the assignor had in the note. He used no words that in and of themselves indicated that he bound or made himself liable in case the maker after demand failed to pay the note. But it was held the law as a legal conclusion 


\section{GUARANTEES}

Suits Against the Maker. In the very few cases that have arisen, where the maker was sued by the transferee of a payee, who had merely stated that he guaranteed payment of the note, the courts are about equally divided as to whether the maker's defenses are cut off. The leading case holding that his defenses are good is Central Trust Co.v. Wyandotte First National Bank. ${ }^{26}$ In that case, the maker delivered the note merely as a memorandum and the payee agreed not to negotiate it or separate it from certain bonds delivered as collateral. The payee, in breach of its promise, sold the note to the defendant. The maker filed a bill in equity asking for the cancellation of the note and return of the bonds on the terms upon which it would have been entitled to same at the payee's hands. The Court was of the opinion that the defendant had no greater rights than the payee and allowed the bill. Mr. Justice Strong said :27

"The note was not indorsed to the Trust Company, and it was not therefore, taken in the ustual course of business by that mode of transfer in which the negotiable paper is usually transferred. Had it been indorsed by the Cook County Bank, it may be that the Trust Company

attached to the words used the liability that follows the indorsement of a promissory note." Sears v. Lentz and Bates, supra note 12 , at p. 659.

"The liabilities implied by indorsing a note can be qualified or restricted only by express terms." Adams v. Blethen, supra note 2I, at p. $2 \mathrm{I}$.

"The language used in the assignment to the note in suit does not negative the implication of the legal liability of the assignor as indorser, and as the words are to be construed, as strongly as their sense will allow, against the assignor, he must be held as indorser." Markey v. Corey, supra note I8, at p. I88. See also Maine Trust \& Banking Co. v. Butler, supra, note 2I.

${ }^{20}$ (1879) 101 U. S. 68; contra: see Patillo v. Alexander, supra note II.

The transferror, if he guarantees payment, more generally adds "protest waived," "waiving demand and notice," or words of similar import. Such words, however, affect only the transferror's conditional promise to pay and merely remove the normally implied conditions of presentment at maturity and notice of dishonor. An indorsement including such words and a mere guarantee by a transferror that the note will be paid seem to be followed by exactly the same legal consequences and such words following a guarantee of payment can have no effect even upon the transferror's undertaking. Robinson $v$. Lair (1879) $3 \mathrm{I}$ Iowa, 9. A transferror's conditional promise to pay is not essential to a negotiation that will destroy the maker's defenses and, since the transferror appears to have the same intent as to the ownership of the instrument whether such words are added or not, it seems clear that the cases where such words are added to the guaranty are not distinguishable, at least when the maker is sued, from those in which a mere guaranty appears. In such cases, it is generally held that the maker's defenses were destroyed.

Robinson v. Lair, supra; Heard v. Dubuque County Bank (I878) 8 Neb. 10; State Nat'l Bank v. Haylen (1883) I4 Neb. 480, 16 N. W. 754; Elgin City Banking Co. v. Zelch (I894) 57 Minn. 487, 59 N. W. $544 ;$ Dunham v. Peterson, supra note 3; McNary v. Farmer's Nat'l Bank (I9I2) 33 Okla. I, I24 Pac. 286; Mangoldt \& Glandt Bank v. Utterback, supra note 3; Jones County Trust \& Savings Bank v. Kurt (I921) I92 Iowa, $965,18 \approx$ N. W. 409 ; contra: Ireland v. Floyd (1914) 42 Okla. 609, 142 Pac. 401.

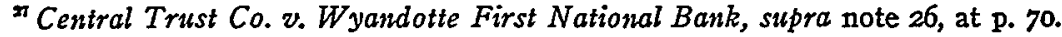


would hold it unaffected by any equities between the maker and the payee. But instead of an indorsement, the president of the Cook County Bank merely guaranteed its payment, and handed over this guaranty to the Trust Company. The note was not even assigned. There was written on it only the following:

'For value received, we hereby guarantee the payment of the within note at maturity or at any time thereafter, with interest at Io per cent. per annum until paid, and agree to pay all costs and expenses paid or incurred in collecting the same. B. F. Allen, Pres't.'

In no commercial sense is this an indorsement, and probably it was not intended as such. Allen had agreed that the note should not be negotiated, and for this reason perhaps it was not indorsed. That a guaranty is not a negotiation, as understood by the law merchant, is certain. Snevily v. Ekel, I Watts \& S. (Pa.) 203; Lamorieux v. Hewit, 5 Wend. (N. Y.) 307; Miller v. Gaston, 2 Hill (N. Y.) I88. In this case, the guaranty on the note was filled up. It expressed fully the contract between the Cook County Bank and the Trust Company. Being express, it can raise no implication of any other contract. 'Expressum facit cessare tacitum.' The contract cannot, therefore, be converted into an indorsement or an assignment. And if it could be treated as an assignment of the note, it would not cut off the defenses of the maker. Such an effect results only from a transfer according to the law merchant; that is, from an indorsement. An assignee stands in the place of his assignor, and takes simply an assignor's rights; but an indorsement creates a new and collateral contract."

It is of importance to note that the proposition that a guaranty of a negotiable instrument is not a negotiation is essential to the conclusion reached by the learned court. But, in each of the cases cited in support of this proposition, a transferror, who had merely guaranteed payment, was sued as indorser by a remote taker. The only question raised was whether the writing made the transferror an indorser and, as a consequence, liable to persons other than his promisee. This, however, is only one of the common consequences of negotiations and it is by no means a necessary or invariable consequence. Since the maker was not sued in those cases and there was no question as to whether his defenses were destroyed, obviously they do not support the essential proposition for which they were cited. But, if the creation. " of a "new and collateral contract" is the respect in which an indorsement differs from an assignment as suggested by the learned court, the conclusion should have been reached that the defendant was an indorser, for the Cook County Bank had entered into a "new and collateral contract."

In the case of Hendrix v. Banhard Bros., ${ }^{28}$ a contrary result was reached where the maker was sued on a note on which the payee had written, "For value received, we hereby warrant the makers of this note financially good on execution." The court said :29

\footnotetext{
${ }^{28}$ (1912) $138 \mathrm{Ga} .473,75$ S. E. 588.

Hendrix v. Bauhard Bros., supra note 28 , at p. 480,75 S. E. at p. 591 .
} 
"The note now under consideration was payable to the order of the payees. When they wrote upon the back of it that for value received they warranted the makers of the note financially good on execution, and sold and delivered it for value to a third person, with no other indorsement (save an entry. of credit), it must be assumed that they intended to accomplish something by so doing. They did not intend to warrant to themselves the financial standing of the makers, nor did they mean that they had received value from themselves for so doing. If not to themselves, then to whom did they make such warranty? Clearly to some other person who should be the owner of the note. Moreover, the statement that the financial status of the makers was warranted 'good on execution' indicates the expectation that execution would issue in favor of some person other than themselves against the makers. But unless this delivery and indorsement carried the legal title to the note to the person to whom it was so delivered, it would remain in the payees and no execution could issue in favor of another person. Nor can we agree with the statement made in Lamourieux v. Hervitt, 5 Wend. (N. Y.) 308, which is cited by the Supreme Court of the United States in the Trust Company case to which reference has already been made, that the payee making such an indorsement upon a note would be liable on his guaranty, not as an indorser of negotiable paper, but as a party to a special contract 'which might have been written on a separate piece of paper as well as on the back of the note.' In that clause inheres the fallacy of the argument. There is a wide difference between writing on a separate piece of paper and a payee's writing something over his name on the back of a promissory note. If he should simply write his name on a separate sheet of blank paper, it would bind him to nothing; but if he writes his name on the back of a promissory note payable to his order, he becomes an indorser. So, if he should write an assignment, or a guaranty, on a separate sheet of paper and sign it, that would be a distinct contract; but when he writes his name on the back of a note payable to his order, the addition of words which either limit or enlarge the usual liability on his part which would arise from a blank indorsement does not destroy the fact that the entry is an indorsement upon a negotiable paper, or prevent its efficacy as a method of passing the legal title upon negotiation, at least unless there is something in the indorsement to show an intention to destroy the negotiable character of the paper."

This reasoning seems irrefutable and entirely applicable to such a case as Central Trust Co. v. Wyandotte First National Bank. It would be absurd, unusual, indeed, for a payee to promise, upon the delivery of a note to another, that the maker would pay unless a change in ownership were intended..$^{30}$ Mere delivery of the instrument indicates the payee's intention to terminate his interest and assignment is

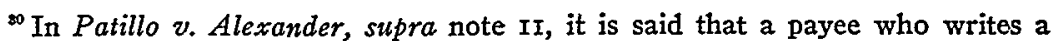
guaranty on the back of a note, not intending to negotiate it but merely to deliver it in pledge, does not thereby pass title to it. This may be'granted and yet the pledgee may have a power to create a title in another, as is the case with a thief of a bearer instrument. That a guaranty may become an indorsement when the instrument passes to a person other than the promisee was recognized in Miller v. Gaston (I849, N. Y. Sup. Ct.) 2 Hill I86, Igr.
} 
generally held to be its legal consequence. But, among merchants, the maker's promise to pay to the order of the payee has always been understood to mean a written order of the payee upon or attached to the instrument. Such an order, as well as a conditional promise to pay, was inferred from the payee's merely writing his signature on the back of the instrument, and a payee who does not wish to undertake as indorser is generally required clearly to show his intention when he transfers the instrument by what he writes on it. But, even where the payee clearly negatives the indorser's undertaking, it is perfectly clear from his writing and delivery of the instrument that he intends to terminate his ownership. Any words, written upon or attached to the instrument, that are reasonably expressive of this intention constitute an indorsement that should destroy the maker's defenses. That such an intention must be inferred where the payee delivers an instrument with his written guaranty thereon seems scarcely debatable.

Suits Against the Payee as Indorser. In the few cases that have arisen where the payee, upon transfer of the instrument, merely stated that he guaranteed payment, most courts have held that the transferror is not an indorser. ${ }^{32}$ This view professes to give effect to the intent of the transferror, assuming from his use of the word "guarantee" that he wills all the legal consequences of an ordinary guaranty promise. For example, in Miller v. Gaston, Bronson, J., said : ${ }^{32}$

"In this state we have not lost sight of the distinction between commercial paper and other written promises to pay money; and a man may guarantee collection or payment of a promissory note, or make some other special undertaking in relation to it, without being regarded either as maker or endorser of the original instrument. The obligation

${ }^{\text {"Snevily v. Ekel (x84I Pa.) I Watt \& S. 203; Lamourieux v. Hewit (I830 }}$ N. Y. Sup. Ct.) 5 Wend., 307; Miller v. Gaston, supra note 30 . In the preceding cases it was held that a payee so indorsing a note was not liable to a remoto holder. Where the guaranty is executed prior to the delivery of the instrument to the payee, it has been held not to be an indorsement. Geiser M'f'g. Co. $v$. Jones \& Toole (I892) 90 Ga. 307, I7 S. E. 8I ; Edgerly v. Lawson (Ig00) 176 Mass. 55I, 57 N. E. IO20. But where the transferror guarantees payment and waives protest he is an indorser and generally held liable to a remote holder. German-Anerican Savings Bank v. Hanna (1904) 124 Iowa, 374, 100 N. W. 57 ; Vanzant, Jones \& Co. v. Arnold, Hamilton \& Johnson (I860) 3I Ga. 2Io.

In Jaffray v. Kraus (I894 Sup. Ct. Gen. T. Ist Dept.) 29 N. Y. Supp. 987, "I hereby charge my separate estate with the payment of this note" was held to be in legal effect a blank indorsement.

In Patillo v. Alexander, supra note II, the same view was held where a payee wrote: "I guarantee attorney's fees up to ten per cent if this note has to be collected by law, on (and?) its prompt payment." The court construed the guarantee to refer only to attorney's fees and held the payee not liable because there had been no presentment and notice, overlooking the possibility that the guaranty might refer to the note and have the effect of the ordinary "protest waived" indorsement.

- Miller v. Gaston, supra note 30 , at p. I88. 
of a guarantor is usually more onerous than that of an endorser; but that consideration does not give the creditor a right to disregard the contract actually made, and substitute another, though less burdensome one, in its place .........

Neither L. P. Hovey nor Gaston can be charged as indorser, for the plain reason that they have severally made an express contract of a different nature, and have not agreed to answer as indorsers. This is not only quite clear upon principle, but it is also settled upon authority. (Meach v. Churchill, 2 Wend. (N. Y.) 63I. Lamourieux v. Hewit, 5 id. 307 . And see Allen v. Rightmere (1823, N. Y.) 20 John. 365.) The contract of guaranty upon this note differs not only in terms, but in its own nature from the contract of indorsement upon commercial paper; and the two things cannot be confounded without losing sight of the agreement made by the parties, and setting up another in place of it."

But it may be well doubted whether a payee so indorsing a note has any desire or intent that the results should be different from those of a "protest-waived" indorsement, where nonpayment by the maker at maturity is the only condition precedent to the indorser's duty to pay. The purpose of the "protest-waived" indorsement is to make the instrument more attractive to a prospective purchaser and this is doubtless the reason why a transferror "guarantees" the payment of paper when he transfers it. If this is true, it seems unlikely that a transferror guaranteeing payment would intend that his transferee should have the power to sue in his own name but be unable to create a similar power in another which could be used as inducement to some other person to purchase the instrument in case his transferee should need to convert his investment into money. Such intent, if entertained, would be unusual and it is not indicated by the mere use of the word "guarantee." As has been pointed out, in order to encourage the circulation of negotiable paper as a substitute for money, it is necessary that a transferror who writes his name on such paper be held to undertake as indorser, unless his intent to the contrary is clearly shown by what he writes. This is not accomplished by the mere use of the word "guarantee." 